\title{
A Discussion on the Teaching Methods in Business English Classes*
}

\author{
TAO Yu \\ University of Shanghai for Science and Technology, Shanghai, China
}

\begin{abstract}
Business English nowadays is expanding into an independent branch. Based on a demonstration of the typical features of business English as an inter-disciplinary subject, this paper aims to discuss case-study teaching method and task-based teaching approach and explore efficient ways to improve the business communicative skills of the learners.
\end{abstract}

Keywords: business English, case-study teaching, task-based approach

Thousands of people in the workplaces every day are dealing with various business activities. The activities may involve business negotiation, cooperation, or solution of conflicts and crisis, but all of them have one thing in common: English is used as a communication tool for business understanding, interpretation, or persuasion. The internationalization requires more and more graduates having a good command of knowledge on business and using English for communication as well. Therefore, business English teaching becomes more and more important in colleges and universities. Consequently, the scope of subjects and the types of classes have expanded in recent years, which has contributed to the independence of business English as a discipline in our country.

\section{Business English}

Business English particularly is used in business environment and it includes daily English, general business English, and business English used for specific purposes. General business English mostly is about the fundamental knowledge and skills for purchase, competition, or negotiation in business activities, while business English for specific purposes is adopted in some professional fields like construction, chemistry, finance, etc. However, business English at the same time shares similar features compared with general English. They both are language types sharing common nature when used as tools for communication, and sharing the same way to use vocabulary and to construct sentences and passages. Therefore, the teaching methods used in general English can be used in the teaching of business English.

From the perspective of both contents and language, business English, which is tightly related to business activities, obviously will be different. Hughes (1995) believes that the difference between business English and general English lies in their different teaching objectives and use of text materials. General English aims to

*Acknowledgements: This research was funded by the project “A Study on Corpus-Based Business Discourse” sponsored by Social Science Fund of University of Shanghai for Science and Technology (Research Grant No. SK18YB32).

TAO Yu, Master of Arts, lecturer, Department of Foreign Languages, University of Shanghai for Science and Technology, Shanghai, China. 
improve the proficiency of using English for communication, while business English, although pays great attention to the basic communicative skill in using English, stresses the business environment in which English is used for communication and cooperation. Therefore, business English, sharing the same language core with general English, is one branch of English for specific purpose and has such particular features as the authentic teaching material, directed by teaching objectives, and being learner-centered. Teaching of business English should consider the special features and emphasize the function and design activities to cultivate students' communicative skills in business circumstances.

\section{Business Teaching}

As ESP teaching, business English combines language and business knowledge. At the same time, it regards communicative skills as one of the most important teaching contents. So business English teaching should design various class activities in order to improve students' skills in language using. Based on the demand of students, the teaching methods to cultivate communicative skills should really satisfy the objectives of business English. Case-study method and task-based teaching approach originate from communication teaching. They both hold the belief that the students are the center of classes, and provide opportunities for students to "learn from doing things". In this way, students actively improve their skills in using English as communication tools through taking part in class activities which are tightly related to authentic business circumstances.

\section{Case-Study Teaching}

There are many names for Case-Study Method, but Case-Study becomes well-known for it is the most important method used by MBA teaching in Harvard Business School. At the beginning of 20th century, Harvard Business School, for a lack of teaching materials, started interviewing enterprise managers and recording the business activities in real workplaces; then edited and compiled the materials into cases for teaching. Case-Study Method was introduced to our country in the 80s of 20th century. Since then, Case-Study began to be used in classes, such as business classes, with high applicability and practicality. In recent years, Case-Study Method has become one of the major methods used in business English teaching.

The core of Case-Study Method is the cultivation of skills to use language for real communication through authentic learning materials and activities. It emphasizes the independent learning and encourages interaction between teachers and students, even the interaction between students. The cases are, "as teaching materials, work with the themes to help students understand relevant concepts and theories through discussion and interaction between students and teachers. In this way, students' ability can be improved to a higher level”. Therefore, case study virtually is one mode of communication teaching, because it regards the communicative function of language as the major objective of learning and teaching.

Case-Study Method roots in Socratic Method, in which the teaching is done through questions and answers. The answers are not the goal of teaching, while the process of answering and the whole interaction are much more important to enlighten students. In Case-Study Method, both learning and teaching are open, and the answers can be diversified. Based on the teaching curriculum, teachers choose the contents, themes, and cases which best match the class objectives. The students work in groups and cooperate with each other. They analyze the case together to find the problems and work out the solutions. The interaction penetrates the whole process directed by the teachers, while the dominant role of students in classes finally can be achieved. 
Case study in business English teaching generally includes five stages: preparation of the case, introduction of the case background to students, analysis and discussion from the students, to summarize the case study by the teacher, and a report on the case from the students. The first stage is very important because it is the foundation which may decide the effectiveness of the case study. Therefore, teachers will have to think carefully whether the case is appropriate in advance. The cases can be chosen from teaching materials, or some classical business cases and teachers can edit cases according to what they have known from books, TV programs, and even their own experiences. Above all, the cases chosen should have its aim and objective so that they can guide the students to understand the theme of that teaching unit well. In the second stage, teachers, sometimes students, talk about the case background to make sound preparation for the following discussion. This part can be finished through reading texts, drawing graphs, and watching relevant videos.

When discussing the case, students have groups. They discuss and analyze the case together, and gradually obtain complete comprehension. Then one of the group members, usually different one each time will be responsible for this part in turns, will have a report on the group work. In this stage, the interaction between teacher and students is extremely strong. The teacher encourages students to express their understandings. At the end of the case study, teacher summarizes all the points from students on their language using and business knowledge used in analyzing the case. In order to improve students' writing skill, students will be required to submit a report so as that they will review their own performance and strengthen the skills used in case analysis. This may help students to be better next time in the activities.

Case-Study Method still needs to be explored for a better application in business English teaching. In teaching practice, teachers may face many problems when collecting cases, especially when there is a need for authenticity of the cases. At the same time, one problem is that most of the business English teachers in our country major in English language and literature. Therefore, they may have a shortage in business knowledge, which may become the biggest challenge for business English teachers.

\section{Task-Based Language Teaching}

Tasks are activities or actions for learners when they are understanding language; usually there are signals designed by teachers to show whether the tasks have been fulfilled (Richards, Platt, \& Weber, 1985). This definition demonstrates that the objective of tasks is to cultivate the skills of students to use the language. As a result, it is necessary for the teachers to design tasks with high pertinence and operability according to the teaching objective. Task-Based Language Teaching basically is one type of communicative teaching approach, in which the students achieve communication through doing tasks. This is what is called as "learning through doing and using”. So both the authenticity of the tasks and learning materials are highlighted. In Task-Based Language Teaching, the center part is students, not the teachers.

Skehan (1996) divides the realization of a task into three phrases: a pre-task phase, a task-proper phase, and a follow-up phase. The pre-task phase provides and rehearses the essential language which will be required to complete the task and rouse students' interest in the task. At the same time, the purposes and ways to fulfill the task must be elaborated for an efficient organization and a sound preparation, and the teachers should encourage students to take part in the activities. For example, in the mock interview, the teacher firstly informs the students of the task objectives. For example, the objective is to learn how to prepare for a successful job interview. Then the students should get more familiar with the skills in interview communication: how to introduce oneself, how to ask or answer questions, etc. In the task-proper phase, students in groups complete 
the task through cooperating with their peers and teachers. As for the mock interview, the students design the interview procedures and personnel arrangement. The cognition and interaction will have a positive impact on the result of learning. In the follow-up phrase, the students report results of the task, and have feedback from the teacher.

In task-based teaching, a final conclusion is unnecessary. It is the task of language learning to have purposeful communicative activities and arrive at a specific goal through a complete process of task accomplishment. A classroom is a real world in which language is used authentically. Discourse, meanings, disagreements are caused by fulfilling tasks. Through interaction, students learn to handle the information gap, reasoning gap, and opinion gap in social communication. The language ability and working ability are combined by tasks through which the potential of learners to use language will be realized. Language as a practical tool for interaction must be instructed to our students, because it is through the course of interaction that learners will gradually understand the purpose of language learning, and will truly learn to use language for interaction.

Firstly, the tasks designed in business English classes must be authentic, and they are possibly the situation the students may face in the future workplaces. Secondly, the tasks must be targeted and make all the students understood the objectives and requirement in order that students can better use the skills when carrying out the tasks. At the same time, the tasks must provide chances for strong interaction, which may help students to improve their cooperative and communicative abilities. Due to its characteristics, Task-Based Language Teaching provides students with simulation opportunities related to business environment. When working on the activities, communicative skills can be cultivated for the active interaction between students and teachers because the tasks are fulfilled on the platform of business knowledge.

\section{Conclusion}

Business English combines business and language; it emphasizes the cultivation of communicative ability of students. Case-study method and task-based teaching can be helpful to create a communication platform for students to learn business and language at the same time. Above all, this platform provides the opportunity for interaction, corporation, and negotiation, through which students learn to solve problems by doing tasks.

\section{References}

Carter, D. (1983). Some propositions about ESP [J]. The ESP Journal, 2(2), 131-137.

Hughes, J. (1995). Business English: Why and when to do a course in general business English [J]. BBC English. He, W. (1999). Harvard business scholl and case-study teaching [J]. Research in Teaching Management Cases. Richards, J., Platt, T., \& Weber, H. (1985). Longman dictionary of applied linguistics. London: Longman.

Skehan, P. (1996). A framework for the implementation of task-based instruction [J]. Applied Linguistics, 17(1), 38-62.

Wang, L. N. \& Duan, J. (2010). The application of case-study in business English teaching [J]. Foreign language and literature. Chong Qing: Sichuan Foreign Languages Institute.

Wang, X. G. (1997). A study on the development of business English [J]. International Business Research.

Zhang, M. J. (2006). Case study teaching - Theory and practice [M]. Beijing: Jiuzhou Press. 